\title{
MANAGEMENT OF SLIPS AND ITS EFFECT ON GROWTH AND PRODUCTION OF 'PÉROLA' PINEAPPLE PLANTS'
}

\author{
DOMINGO HAROLDO REINHARDT ${ }^{2}$, ANA PATRÍCIA MASCARENHAS SOUZA ${ }^{3}$ RANULFO CORREA CALDAS², \\ JOSÉ DOS PRAZERES ALCÂNTARA ${ }^{4}$, ALBERTO ALVES DE ALMEIDA ${ }^{4}$
}

\begin{abstract}
The lack of good quality planting material has limited the expansion and contributed to yield reduction of the Brazilian pineapple culture. Alternatives of 'Pérola' pineapple slips management were studied aiming at obtaining superior planting material within a shorter time period and making good use of healthy slips of low vigor, that are commonly discarded by growers. Two experiments were carried out at the Experimental Field of Embrapa Cassava \& Fruits, Cruz das Almas, Bahia, Brazil, and another one in a commercial plantation in the region of Itaberaba, BA, using blocks or entirely randomized designs with at least four replications. In the first one, the development of slips of different initial sizes ( 6 to $20 \mathrm{~cm}$ long), when grown on mother plants after fruit harvest, was compared with that of slips grown in a nursery after their removal from the mother plants. It became clear that larger slips grow more vigorously and that the removal from the mother plant delays their growth. However, results from the second study showed that those slips grown in nursery had vegetative and agronomic performance similar to that of conventional slips and close to that of plantlets produced from plant stem sections. Independently from the type of planting material used, the larger ones presented a more vigorous growth and produced higher yields. In the third study, it was observed the influence of mineral fertilization, pest control and growth regulator application after fruit harvest on slip development. The treatments applied did not significantly accelerate slip growth. Slips reached $50 \mathrm{~cm}$ length and at least $300 \mathrm{~g}$ fresh weight within 90 days after fruit harvest, indicating that vigorous plants have enough nutritional storage material for slips development.
\end{abstract}

Index terms: Ananas comosus, propagation, slips, plantlets, cultural practices.

\section{MANEJO DE MUDAS NA CEVA E SEU EFEITO SOBRE O CRESCIMENTO E PRODUÇÃO DO ABACAXIZEIRO 'PÉROLA'}

RESUMO - A escassez de mudas de boa qualidade tem limitado a expansão e contribuído para a redução da produtividade da abacaxicultura brasileira. Alternativas de manejo de mudas do tipo filhote do abacaxi cv. Pérola foram estudadas, visando a obtenção de material de plantio superior, em menor espaço de tempo, e o aproveitamento de mudas sadias de menor vigor que têm sido descartadas pelo produtor. Dois experimentos foram conduzidos no Campo Experimental da Embrapa Mandioca e Fruticultura e outro em abacaxizal comercial da região de Itaberaba, Bahia, usando-se delineamentos em blocos ou inteiramente casualizados com, pelo menos, quatro repetições. No primeiro, foi comparado o desenvolvimento de mudas do tipo filhote, de vários tamanhos iniciais $(6 \mathrm{~cm}$ a $20 \mathrm{~cm}$ ), durante a ceva em plantas pouco vigorosas, com aquele em viveiro, após removidas das plantas. Ficou evidente que mudas maiores crescem com mais vigor e que a sua remoção da planta-mãe atrasa o seu crescimento. No entanto, os resultados obtidos no segundo experimento mostraram que o desempenho vegetativo e agronômico das mudas enviveiradas foi similar ao dos filhotes convencionais e próximo ao de plântulas (mudas produzidas de pedaços do caule). Independentemente do tipo de material de plantio usado, mudas grandes apresentaram crescimento mais vigoroso, determinando maior produtividade das plantas. No terceiro experimento, foram avaliados os efeitos de tratamentos de adubação, controle fitossanitário e fitorreguladores de crescimento, durante a ceva de mudas do tipo filhote, sobre o seu crescimento. Os tratamentos não aceleraram significativamente o crescimento das mudas, as quais atingiram comprimento médio superior a $50 \mathrm{~cm}$ e peso fresco médio próximo ou superior a $300 \mathrm{~g}$, aos 90 dias após a colheita dos frutos, indicando que plantas vigorosas têm reservas nutritivas suficientes para o desenvolvimento das mudas.

Termos para indexação: Ananas comosus, propagação, filhotes, plântulas, práticas culturais.

\section{INTRODUCTION}

In Brazil, good quality pineapple planting material has been known to be scarce and expensive (Reinhardt, 1998b). In many production regions the low availability of vigorous and healthy slips and suckers has limited the expansion of the cultivated area and contributed to the reduction of productivity increases, from $152 \%$ during the period 1970 to 1990 , to about $6 \%$ during the 1990 decade (Reinhardt \& Souza, 2000).

The offer of planting material of superior quality may be increased by several measures, such as improvement of plant management during the vegetative and reproductive phases, flowering forcing in less hot seasons and daytimes, use of adequate planting densities, supply of nutrients and water in a balanced way and efficient control of pests and diseases, among other cultural practices (Reinhardt, 1998a). Those practices tend to increase plant vigor, with the formation of heavier and more numerous plantlets (Py, 1979; Py et al., 1984).

However, pineapple slips have not received the due attention by growers during their development on the mother plants. In general, in
Brazil no cultural practices are applied to plants and slips during their development after fruit harvest (Cunha \& Reinhardt, 1994; Reinhardt, 1998a,b), what is in contrast with sucker management in 'Smooth Cayenne' plantations in Mexico (Rebolledo et al., 1998) and other countries (IRFA, 1984). The development of 'Pérola' pineapple slips on the plants, after fruit harvest, usually takes two to six months (Reinhardt et al., 2000), but it may require a longer period under unfavorable climatic conditions.

Cultural practices that supply nutrients contribute to better sanitary conditions and stimulate growth, may reduce the time lapse needed for slips development and improve their quality. This hypothesis was studied in this work, in addition to the possibility to transform small slips which are usually removed from the mother plants together with the larger slips and then discarded at the preplanting selection stage, into adequate planting material by a growth period in nursery. Hence, this work aimed at evaluating these alternatives of 'Pérola' pineapple slips management and to compare the field performance of those nursery slips with that of conventional slips and of plantlets produced from stem sections.

\footnotetext{
${ }^{1}$ (Trabalho 168/2002). Recebido: 05/09/2002. Aceito para publicação: 09/05/2003. Trabalho parcialmente financiado pelo Banco do Nordeste do Brasil/ETENE/ FUNDECI.

${ }^{2}$ Pesquisador, Embrapa Mandioca e Fruticultura, Cx. P. 7, 44.380-000 Cruz das Almas, BA, dharoldo@cnpmf.embrapa.br

${ }^{3}$ Engenheiro Agrônomo, Secretaria de Agricultura da Bahia, Salvador, BA.

${ }^{4}$ Engenheiro Agrônomo, EBDA, Itaberaba, BA, fone (0xx75) 251 1716, aalves@ sendnet.com.br
} 


\section{MATERIAL AND METHODS}

Three experiments were carried out, two of them at the Experimental Field of Embrapa Cassava \& Fruits, Cruz das Almas, Bahia, Brazil, and the other in a commercial field of Itaberaba, main pineapple production region in Bahia State, in the period from 1998 to 2000. Cruz das Almas is located in the Coastal Table Lands of the Reconcavo Baiano region, presents a warm and sub-humid climate with annual average temperature of $24^{\circ} \mathrm{C}$ and annual rainfall of $1200 \mathrm{~mm}$. Itaberaba has a semiarid climate, with irregular rains and annual total rainfall of 600 to $800 \mathrm{~mm}$. In both regions the predominant soil is a yellow, deep latosoil with intermediate texture and acidity, low phosphorous and aluminum and intermediate potassium, calcium and magnesium contents.

Experiment I - In this experiment was compared the vegetative development of small slips while transferred to a nursery and while kept attached to their mother-plants in the field. The following treatments were studied: A - Slips on mother-plants, initial length of 6 to $10 \mathrm{~cm}$; B Slips on mother-plants, length of 11 to $15 \mathrm{~cm}$; C-Slips on mother-plants, length of 16 to $20 \mathrm{~cm}$; D - Slips in nursery, initial length of 6 to $10 \mathrm{~cm}$; E -Slips in nursery, length of 11 to $15 \mathrm{~cm}$; F-Slips in nursery, length of 16 to $20 \mathrm{~cm}$.

The experimental design was a completely randomized one, with six treatments ( 2 sites of growth $\mathrm{x} 3$ initial lengths) and ten replications, each one constituted by the slips from one plant. The slips for the nursery were harvested from 30 plants, separated into the three length intervals and their initial fresh weights determined. Thereafter the slips were planted in seedbeds in a spacing of $15 \times 15 \mathrm{~cm}$. At the same day, other 30 plants were marked in the field and their slips selected and identified for the three length ranges studied. These slips were kept on their mother-plants and their growth evaluated in comparison to that of the nursery slips. At 60,90 and 120 days after the beginning of the experiment were determined the length and the fresh and dry weights of the slips from 10 plants at each evaluation date for each of the treatments studied.

In the nursery slips received one solid fertilization and irrigation on alternate days, whereas the slips on the mother-plants did not get any cultural practices, except for one weeding.

Experiment II - In this experiment was observed the performance of slips obtained in nursery, during the first crop cycle in the field, in comparison to conventional slips and to plantlets produced from stem sections. The treatments studied were the three types of planting material, that were conventional slips, nursery slips and plantlets, and two slips sizes (lengths from 25 to $34 \mathrm{~cm}$ and 35 to $44 \mathrm{~cm}$ ). These planting materials were placed in double rows, in a spacing of $90 \times 40 \times 40 \mathrm{~cm}$, in the middle of July 1998. Each plot had a total of 100 plants and 62 useful plants. The experimental design was a randomized blocks one, with five replications. The cultural practices applied during the crop cycle were those recommended by Cunha et al. (1995). The flowering forcing treatment was done on July/99, but there occurred natural flower differentiation from June, defining a fruit harvest period from December/ 1999 to January/2000.

Treatment evaluations were based upon plant growth data, represented by the dimensions and fresh and dry weights of ' $D$ ' leaves, measured at 4, 6, 8 and 10 months after planting, using samples of four leaves per plot per evaluation. At fruit harvest were determined the number of slips per plant, the productivity and fruit weight, from all useful plants in the plots, and the fruit dimensions (length, largest diameter), crown length and weight and fruit pulp quality (total soluble solids and total titrable acidity), based upon samples of $10 \%$ of the fruits harvested.

Experiment III - The experiment was installed in a commercial plantation of the Fazenda Alagoana belonging to Mr. Jorge Gomes dos Santos, Itaberaba, right after the end of fruit harvest of the first crop cycle. In a randomized blocks design with four replications were studied the following treatments:

A - Control (water); B - Foliar fertilization (two sprays at 15 and 30 days); $\mathrm{C}$ - Foliar fertilization (four sprays at 15, 30, 45 and 60 days); D - Foliar fertilization (six sprays at 15,30, 45, 60,75 and 90 days); E - Solid fertilization (at 15 days); F - Liquid insecticide (at 15 and 30 days); $\mathrm{G}$ - Treatments $\mathrm{C}+\mathrm{F} ; \mathrm{H}$ - Spraying of the growth regulator $\mathrm{GA}_{3}$ at $50 \mathrm{mg} \mathrm{L}^{-1}$ (c.p. Pro-Gibb, at $500 \mathrm{mg} \mathrm{L}^{-1}$ ) at 15 and 30 days; I - Spraying of the growth regulator tebuconazole at $150 \mathrm{mg} \mathrm{L}^{-1}$ (c.p. Folicur $200 \mathrm{CE}$, at $750 \mathrm{mg} \mathrm{L}^{-1}$ ), at 15 and 30 days.

All the time intervals mentioned refer to the date of fruit harvest end. All the sprays were done with a knapsack pump, except for the solid fertilization, applying about $30 \mathrm{~mL} \mathrm{plant}^{-1}$ directing the jet to the slips. A surfactant was added to the solutions. In the foliar fertilization were used urea at $3 \%$ and potassium chloride at $2 \%$, being added in every other spray the foliar fertilizer Wuxal at 2\% (20-00-15 + $4 \mathrm{Mg}+$ micronutrients). The solid fertilization (treatment $\mathrm{E}$ ) supplied $4 \mathrm{~g}$ of urea $+2.7 \mathrm{~g}$ of potassium chloride per plant. The insecticide used was vamidothion (c.p. Kilval, at $1 \mathrm{~mL} \mathrm{~L}^{-1}$ ).

Each plot had $36.0 \mathrm{~m}^{2}$, with 40 useful plants, in addition to borders on all sides formed by 56 plants, giving a total of 96 plants per plot. At 0 , $30,60,90$ and 120 days were determined the length and the fresh and dry weights of the slips, based upon samples of 16 slips per plot (two slips per plant, in $20 \%$ of the useful plants).

In all experiments data were submitted to the analyses of variance and averages compared by the Tukey test at $5 \%$ of probability.

\section{RESULTS AND DISCUSSION}

Both slips size and the site of slips development (nursery or mother-pant) influenced significantly their growth (Table 1), without having a significant interaction between these factors (data not shown). Large slips presented higher growth rates, especially on weight basis, with increasing differences in relation to the other sizes studied, as long as the experimental period advanced. Differences were statistically significant for slips fresh and dry weights, in all evaluation dates, for large slips in relation to small ones and also in relation to slips of intermediate size, for most of the evaluations done. In the case of elongation growth (height) significant differences occurred from the evaluation at 90 days. These results may be attributed to the differences in volume of nutritional storage material available in the slips at the beginning of their development stage after fruit harvest, which was the highest for the large ones. At that time, these slips presented an average fresh weight of $91 \mathrm{~g}$, whereas the weights of intermediate and small slips were $48 \mathrm{~g}$ and $24 \mathrm{~g}$, respectively. In addition, smaller slips have a lower photosynthetic capacity due to their reduced leaf area, their initial development being dependent on their storage material and the motherplant activity (Py et al., 1984).

When kept attached to the mother-plant, slips had a superior growth in relation to the nursery slips, both in length and fresh weight, for most of the evaluation dates (Table 1). These results suggest that the trauma suffered by the slips at their transplantation to the nursery affects their development. In addition, the mother-plant is an important source of nutrients for the slips, which become the main sinks after fruit removal (Lima et al., 2001 e 2002). In spite of growing more slowly, nursery slips developed enough to reach minimum size and weight $(30 \mathrm{~cm}$ and $200 \mathrm{~g}$ ) for their planting in the field, after about four to five months in nursery (data not shown).

The agronomic performance of large and small slips, obtained by a nursery phase, was evaluated in the second experiment, in comparison to the performance of other types of planting material. There was no significant interaction between type and size of the planting material studied and hence each factor will be discussed apart.

The vegetative growth of the plants, expressed by weight and dimensions of ' $D$ ' leaves, was significantly influenced by size and type of planting material (Table 2). Large planting material determined higher values for all variables evaluated, from four to ten months after planting. These results confirmed those reported by several authors (Gaillard, 1969; Reinhardt et al., 1986), thereby reinforcing the technical recommendation to separate the planting material into different size and/ 
TABLE 1 - Effect of initial size and site (mother-plant and nursery) of 'Pérola' pineapple slips on their growth, expressed by length (Len) (cm) and fresh (FW) and dry (DW) weights, during time intervals of 60, 90 and 120 days after fruit harvest. Cruz das Almas, BA, 1998.

\begin{tabular}{lccccccccc}
\hline Treatments & \multicolumn{3}{c}{ At 60 days } & \multicolumn{3}{c}{ At 90 days } & \multicolumn{2}{c}{ At 120 days } \\
\cline { 2 - 8 } & Len & FW & DW & Len & FW & DW & Len & FW \\
\hline Size & & & & & & & \\
Large & $5.1 \mathrm{a}$ & $24.0 \mathrm{a}$ & $8.8 \mathrm{a}$ & $6.3 \mathrm{a}$ & $42.2 \mathrm{a}$ & $12.0 \mathrm{a}$ & $12.3 \mathrm{a}$ & $71.3 \mathrm{a}$ & $24.6 \mathrm{a}$ \\
Intermediate & $4.7 \mathrm{a}$ & $16.7 \mathrm{~b}$ & $4.7 \mathrm{~b}$ & $5.1 \mathrm{ab}$ & $33.8 \mathrm{ab}$ & $7.6 \mathrm{~b}$ & $6.7 \mathrm{~b}$ & $42.4 \mathrm{~b}$ & $22.6 \mathrm{a}$ \\
Small & $4.1 \mathrm{a}$ & $13.5 \mathrm{~b}$ & $3.6 \mathrm{~b}$ & $3.7 \mathrm{~b}$ & $21.0 \mathrm{~b}$ & $4.7 \mathrm{c}$ & $5.8 \mathrm{~b}$ & $20.8 \mathrm{c}$ & $9.8 \mathrm{~b}$ \\
Site & & & & & & & & \\
Mother-plant & $5.9 \mathrm{a}$ & $25.2 \mathrm{a}$ & $5.8 \mathrm{a}$ & $5.4 \mathrm{a}$ & $41.6 \mathrm{a}$ & $8.1 \mathrm{a}$ & $11.0 \mathrm{a}$ & $49.1 \mathrm{a}$ & $19.2 \mathrm{a}$ \\
Nursery & $3.4 \mathrm{~b}$ & $10.9 \mathrm{~b}$ & $5.3 \mathrm{a}$ & $4.6 \mathrm{a}$ & $23.7 \mathrm{~b}$ & $8.1 \mathrm{a}$ & $5.5 \mathrm{~b}$ & $40.6 \mathrm{~b}$ & $18.7 \mathrm{a}$ \\
\hline C.V. $(\%)$ & 46.1 & 46.4 & 36.7 & 53.3 & 59.5 & 20.7 & 45.5 & 63.3 & 27.0 \\
\hline
\end{tabular}

Values followed by the same letter in the column (within size and site) do not differ from one another by the Tukey test at $5 \%$.

Large -16 to $20 \mathrm{~cm}$ of length; Intermediate -11 to $15 \mathrm{~cm}$; Small -6 to $10 \mathrm{~cm}$.

or weight ranges, what allows to get a better uniformity of plant development within each field plot (Cunha et al., 1995; Rebolledo et al., 1998; Reinhardt et al., 2000). Larger leaf area and higher volume of nutritional storage material presented by large planting material result in a biological production and fresh and dry mass accumulation superior to that of small slips or plantlets. Therefore, larger planting material needs a shorter cycle, being the use of planting material of several sizes one of the strategies to get an ordered pineapple production (Giacomelli et al., 1979; Reinhardt et al., 1987).

In relation to the factor type of planting material, the treatment effects on plant growth were less evident (Table 2). However, values obtained were always higher for plants coming from plantlets. There was no significant difference for ' $\mathrm{D}$ ' leaf length, but its width was significantly smaller for nursery slips than that of plantlets, at three of the four evaluation dates. The same happened in relation to fresh weight, with significant differences at four, eight and ten months, and for dry weight at four and eight months. In all growth evaluations, the plants originated from conventional slips presented an intermediate performance in comparison to the two other types of planting material. The differences in favor of plantlets observed in this experiment may be partly attributed to their larger initial average weight.

The differences among treatments observed on plant vegetative growth determined similar results for the yield ( $\mathrm{kg}$ of fruits harvested ha $\left.{ }^{1}\right)$ obtained in the treatments studied (Table 3). This was significantly higher for large planting material and for the plantlets type of it in relation to, respectively, small planting material and to nursery slips, with conventional slips having an intermediate behavior, without statistical differences with respect to the other two types of planting materials. To these results contributed the differences of average weights of fruits with crowns in the treatments studied, especially in the case of the factor size of planting material, reinforcing data from Cunha et al. (1993) obtained for the same cultivar under similar environmental conditions.

There were no significant differences for fruit dimensions, whose measurements were based upon $10 \%$ of fruits harvested (Table 3 ). The same occurred with respect to the production of slips per plant, crown weight and length and qualitative fruit characteristics, such as total soluble solids (TSS) and total titrable acids (TTA) contents and their ratio TSS/TTA, except for the higher crown weight of nursery slips in relation to that of slip (Table 4). The values obtained for the variables were typical for the cultivar Pérola, which is characterized by a fruit with a conical format, high number of slips, small crowns, low pulp acidity and high ratio.

In synthesis, the agronomic performance of low vigor slips, recuperated by a nursery period, was satisfactory, reaching the same statistical level of that of conventional slips. Such a result suggests the possibility to make use of those slips, reducing the loss of planting

TABLE 2 - Length $(\mathrm{cm})$, width $(\mathrm{cm})$, fresh weight (FW) and dry weight (DW) $(\mathrm{g})$ of ' $\mathrm{D}$ ' leaf of 'Pérola' pineapple plants as a function of size and type of planting material, at four, six, eight and ten months after planting. Cruz das Almas, BA, 1999.

\begin{tabular}{|c|c|c|c|c|c|c|c|c|c|c|c|c|c|c|c|c|}
\hline \multirow[t]{2}{*}{ Treatment } & \multicolumn{4}{|c|}{4 months } & \multicolumn{4}{|c|}{6 months } & \multicolumn{4}{|c|}{8 months } & \multicolumn{4}{|c|}{10 months } \\
\hline & Length & Width & FW & DW & Length & Width & FW & DW & Length & Width & FW & DW & Length & Width & FW & DW \\
\hline \multicolumn{17}{|l|}{ Size } \\
\hline Large & $46.3 a$ & $3.8 \mathrm{a}$ & $17.0 \mathrm{a}$ & $3.3 \mathrm{a}$ & $59.0 \mathrm{a}$ & $5.2 \mathrm{a}$ & $18.7 \mathrm{a}$ & $4.3 \mathrm{a}$ & $71.9 \mathrm{a}$ & $6.9 \mathrm{a}$ & $56.6 \mathrm{a}$ & $7.9 \mathrm{a}$ & $88.9 \mathrm{a}$ & $8.2 \mathrm{a}$ & $85.3 \mathrm{a}$ & $13.2 \mathrm{a}$ \\
\hline Small & $38.8 b$ & $3.2 \mathrm{~b}$ & $13.4 b$ & $2.7 \mathrm{~b}$ & $50.5 b$ & $4.5 b$ & $11.4 \mathrm{~b}$ & $3.4 \mathrm{~b}$ & $67.8 b$ & $6.4 \mathrm{~b}$ & $48.6 \mathrm{~b}$ & $6.8 b$ & $82.0 \mathrm{~b}$ & $7.4 \mathrm{a}$ & $73.0 \mathrm{~b}$ & $11.3 \mathrm{~b}$ \\
\hline \multicolumn{17}{|l|}{ Type } \\
\hline Plantlet & $45.6 \mathrm{a}$ & $3.9 \mathrm{a}$ & $17.6 \mathrm{a}$ & $3.4 \mathrm{a}$ & $56.5 \mathrm{a}$ & $5.1 \mathrm{a}$ & $21.2 \mathrm{a}$ & $4.7 \mathrm{a}$ & $70.8 \mathrm{a}$ & $6.8 \mathrm{a}$ & $58.6 \mathrm{a}$ & $7.8 \mathrm{a}$ & $87.0 \mathrm{a}$ & $8.1 \mathrm{a}$ & $83.0 \mathrm{a}$ & $13.0 \mathrm{a}$ \\
\hline Slip & $43.8 \mathrm{a}$ & $3.5 \mathrm{ab}$ & $15.1 \mathrm{ab}$ & $2.8 \mathrm{~b}$ & $54.5 \mathrm{a}$ & $5.1 \mathrm{a}$ & $19.9 \mathrm{a}$ & 3.9ab & $70.8 \mathrm{a}$ & $6.7 \mathrm{a}$ & $53.6 \mathrm{ab}$ & $7.1 \mathrm{~b}$ & $85.5 \mathrm{a}$ & $7.4 \mathrm{a}$ & 77.9ab & $11.9 \mathrm{a}$ \\
\hline Nursery-Slip & $38.0 \mathrm{a}$ & $3.2 \mathrm{~b}$ & $13.0 \mathrm{~b}$ & $27 \mathrm{~b}$ & $53.2 \mathrm{a}$ & $4.3 b$ & $19.2 \mathrm{a}$ & $3.5 \mathrm{~b}$ & $68.2 \mathrm{a}$ & $6.5 b$ & $45.5 \mathrm{~b}$ & $7.1 \mathrm{~b}$ & $83.9 \mathrm{a}$ & $7.3 \mathrm{a}$ & $76.5 b$ & $11.8 \mathrm{a}$ \\
\hline C.V. (\%) & 17.2 & 11.0 & 15.4 & 16.1 & 9.1 & 10.8 & 16.5 & 14.2 & 4.4 & 3.3 & 18.4 & 7.5 & 4.7 & 19.9 & 5.8 & 10.5 \\
\hline
\end{tabular}

Values followed by the same letter in the column (within size and type) do not differ from one another by the Tukey test at $5 \%$.

TABLE 3 - Productivity $\left(\mathrm{kg} \mathrm{ha}^{-1}\right)$ and fruit weight with crown $(\mathrm{g})$, length $(\mathrm{cm})$, diameter $(\mathrm{cm})$ and core diameter $(\mathrm{cm})$ of 'Pérola' pineapple as a function of size and type of planting material Cruz das Almas, BA, 1999.

\begin{tabular}{|c|c|c|c|c|c|}
\hline Treatment & Productivity & Fruit weight with crown ${ }^{z}$ & Fruit length $^{\mathrm{Z}}$ & Fruit diameter $^{z}$ & Fruit core diameter $^{2}$ \\
\hline \multicolumn{6}{|l|}{ Size } \\
\hline Large & $38,697 \mathrm{a}$ & $1,116.9 \mathrm{a}$ & $19.5 \mathrm{a}$ & $10.0 \mathrm{a}$ & $1.5 \mathrm{a}$ \\
\hline Small & $29,528 b$ & $925.0 \mathrm{~b}$ & $18.7 \mathrm{a}$ & $10.4 \mathrm{a}$ & $1.5 \mathrm{a}$ \\
\hline \multicolumn{6}{|l|}{ Type } \\
\hline Plantlet & $37,220 \mathrm{a}$ & $1,097.5 \mathrm{a}$ & $19.9 a$ & $10.7 \mathrm{a}$ & $1.4 \mathrm{a}$ \\
\hline Slip & $33,839 \mathrm{ab}$ & $988.8 \mathrm{a}$ & $17.1 \mathrm{a}$ & $9.8 \mathrm{a}$ & $1.5 \mathrm{a}$ \\
\hline Nursery slip & $31,265 \mathrm{~b}$ & $976.5 \mathrm{a}$ & $20.3 \mathrm{a}$ & $10.2 \mathrm{a}$ & $1.5 \mathrm{a}$ \\
\hline C.V. $(\%)$ & 17.0 & 3.8 & 7.1 & 10.9 & 9.9 \\
\hline
\end{tabular}

${ }^{\mathrm{z}}$ Values of 20 replications per size and 12 replications per type of planting material.

Values followed by the same letter in the column (for size and type), do not differ from one another by the Tukey test at $5 \%$. 
TABLE 4 - Slip production per plant, weight $(\mathrm{g})$ and length $(\mathrm{cm})$ of fruit crown, total soluble solids (TSS) $(\%)$ and total titrable acidity (TTA) (mL NaOH $0,1 \mathrm{~N} / 10 \mathrm{~mL}$ ) contents and TSS/TTA ratio of 'Pérola' pineapple juice, as a function of size and type of planting material. Cruz das Almas, BA, 1999.

\begin{tabular}{|c|c|c|c|c|c|c|}
\hline Treatment & Slips per plant & Crown weight $^{\mathrm{Z}}$ & Crown length $^{\mathrm{Z}}$ & $\mathrm{TSS}^{\mathrm{z}}$ & TTA $^{\mathrm{z}}$ & Ratio TSS/TTA \\
\hline \multicolumn{7}{|l|}{ Size } \\
\hline Large & $6.4 \mathrm{a}$ & $63.5 \mathrm{a}$ & $19.5 \mathrm{a}$ & $14.02 \mathrm{a}$ & $5.5 \mathrm{a}$ & $2.7 \mathrm{a}$ \\
\hline Small & $5.6 \mathrm{a}$ & $64.8 \mathrm{a}$ & $18.5 \mathrm{a}$ & $13.71 \mathrm{a}$ & $5.5 \mathrm{a}$ & $2.6 \mathrm{a}$ \\
\hline \multicolumn{7}{|l|}{ Type } \\
\hline Plantlet & $6.2 \mathrm{a}$ & $63.0 \mathrm{ab}$ & $19.9 \mathrm{a}$ & $14.23 \mathrm{a}$ & $5.4 \mathrm{a}$ & $2.8 \mathrm{a}$ \\
\hline Slip & $6.0 \mathrm{a}$ & $58.7 b$ & $17.1 \mathrm{a}$ & $13.70 \mathrm{a}$ & $5.5 a$ & $2.6 \mathrm{a}$ \\
\hline Nursery slip & $5.8 \mathrm{a}$ & $70.9 \mathrm{a}$ & $20.3 \mathrm{a}$ & $13.68 \mathrm{a}$ & $5.5 \mathrm{a}$ & $2.6 \mathrm{a}$ \\
\hline C.V. $(\%)$ & 36.4 & 16.3 & 12.5 & 7.0 & 11.2 & 11.9 \\
\hline
\end{tabular}

${ }^{\mathrm{z}}$ Values from 20 replications per size and 12 replications per type of planting material.

Values followed by the same letter in the column (for size and type) do not differ from one another by the Tukey test at $5 \%$.

material. The additional investment in the nursery phase may be viable when there is a limited availability of good quality and high cost planting material, what is especially critical in new production regions located at long distances from sources of planting material.

The improvement of slips management was the issue of the third experiment, by assessing the effect of cultural practices on slips development after fruit harvest. The plants from the pineapple planting used were vigorous ones, as shown by their size $(29.2 \mathrm{~cm})$ and weight $(162.5 \mathrm{~g})$ at the beginning of the study, right after the fruit harvest end (Table 5). Slips grew very fast during the following 120 days, practically doubling their length and fresh weight.

Looking at the growth rates, expressed as increases of length and fresh and dry weights at the intervals from 60 to 90 days and 90 to

TABLE 5 - Effect of post-harvest cultural practices on length (cm) and fresh weight (g) of 'Pérola' pineapple slips, at 60, 90 and 120 days after fruit harvest. Itaberaba, BA, 1999.

\begin{tabular}{ccccccccc}
\hline Treatment & \multicolumn{4}{c}{ Length } & \multicolumn{4}{c}{ Fresh weight } \\
\cline { 2 - 9 } & Initial & $\begin{array}{c}60 \\
\text { days }\end{array}$ & $\begin{array}{c}90 \\
\text { days }\end{array}$ & $\begin{array}{c}120 \\
\text { days }\end{array}$ & Initial & $\begin{array}{c}60 \\
\text { days }\end{array}$ & $\begin{array}{c}90 \\
\text { days }\end{array}$ & $\begin{array}{c}120 \\
\text { days }\end{array}$ \\
\hline A & 29.7 & 50 & 59 & 68 & 163.6 & 264 & 321 & 333 \\
B & 32.2 & 49 & 60 & 71 & 161.5 & 284 & 306 & 314 \\
C & 26.2 & 47 & 61 & 74 & 173.2 & 260 & 298 & 318 \\
D & 31.5 & 50 & 62 & 73 & 149.5 & 269 & 319 & 331 \\
E & 29.0 & 45 & 58 & 70 & 157.0 & 250 & 310 & 320 \\
F & 28.6 & 47 & 54 & 67 & 178.0 & 271 & 323 & 333 \\
G & 28.0 & 47 & 53 & 61 & 170.2 & 294 & 309 & 328 \\
H & 31.0 & 49 & 58 & 67 & 163.5 & 278 & 262 & 269 \\
I & 27.0 & 45 & 51 & 62 & 145.6 & 247 & 289 & 297 \\
\hline Averages & 29.2 & 48 & 57 & 68 & 162.5 & 269 & 307 & 315 \\
\hline
\end{tabular}

Treatments: A - Control; B - Foliar fertilization (two applications); C - Foliar fertilization (four applications); D - Foliar fertilization (six applications); E Solid fertilization; F-Liquid insecticide; G -Treatment C+F; H - Spraying $\left(\mathrm{GA}_{3}\right)$; I - Spraying (tebuconazole).

120 days after trial start, becomes evident that there was no significant effect of the treatments studied on slips growth (Table 6). Even in the control, without any cultural practice applied to the slips, their growth rate was high reaching almost $20 \mathrm{~cm}$ or about $100 \mathrm{~g}$ (fresh weight) from 60 to 90 days. During the following 30 days, slips growth was slower (about $10 \mathrm{~cm}$ and $70 \mathrm{~g}$ ) in all treatments. Such slowing down of growth is normal, as pineapple plant growth, and that of its organs, is represented by a sigmoid curve, with increasing rates during the first phase of organ development, followed by decreasing growth rates in the second stage (Reinhardt and Medina, 1992).

At 60 days of development after fruit harvest, slips presented appropriate size and weight for their use as planting material in the field (average length of $48 \mathrm{~cm}$ and average fresh weight of $269 \mathrm{~g}$ ) (Table 5). These results showed that plants used in this study presented high vigor and enough nutritional storage material in order to assure excellent slips development. Under such conditions becomes evident that in pineapple plantings with well developed, vigorous and healthy plants, the application of fertilizers, growth regulators and pesticides (in the case of low pest infestation) is not needed during slips development after fruit harvest. However, this result may not be generalized, requiring new studies in pineapple plantings with low vigor plants.

TABLE 6 - Effect of post-harvest cultural practices on growth of 'Pérola' pineapple slips, expressed by length $(\mathrm{cm})$, fresh $(\mathrm{FW})$ and dry (DW) weights (g), at the intervals from 60 to 90 days (First evaluation) and from 90 to 120 days (Second evaluation) after treatments applications. Itaberaba, BA, 1999.

\begin{tabular}{ccrrrrr}
\hline Treatment & \multicolumn{5}{c}{ First evaluation (90 dias) } & \multicolumn{5}{c}{ Second evaluation (120 dias) } \\
\cline { 2 - 7 } & Length & \multicolumn{1}{c}{ FW } & DW & Length & FW & DW \\
\hline A & 19.8 & 100.4 & 6.8 & 9.3 & 67.0 & 12.7 \\
B & 15.0 & 125.0 & 10.7 & 11.8 & 48.2 & 8.1 \\
C & 21.0 & 86.8 & 8.2 & 13.3 & 73.5 & 10.3 \\
D & 19.3 & 119.5 & 12.2 & 11.3 & 67.3 & 12.0 \\
E & 18.7 & 92.8 & 6.8 & 12.5 & 107.3 & 10.3 \\
F & 18.7 & 93.3 & 7.1 & 13.8 & 57.6 & 10.2 \\
G & 19.9 & 123.8 & 12.1 & 9.0 & 105.8 & 18.4 \\
H & 18.7 & 114.5 & 9.1 & 9.5 & 61.0 & 6.8 \\
I & 15.5 & 101.4 & 6.3 & 11.8 & 85.0 & 8.8 \\
\hline Averages & 18.5 & 106.4 & 8.8 & 11.3 & 74.7 & 10.8 \\
\hline F Test & N.S & N.S & N.S & N.S & N.S & N.S \\
\hline C.V.(\%) & 27.8 & 23.3 & 45.6 & 50.3 & 60.8 & 56.3 \\
\hline V
\end{tabular}

Values represent averages of 32 measurements. N.S = not significant.

Treatments: A - Control; B - Foliar fertilization (two applications); C - Foliar fertilization (four applications); D - Foliar fertilization (six applications); E Solid fertilization; F-Liquid insecticide; G -Treatment C+F; H - Spraying $\left(\mathrm{GA}_{3}\right)$; I - Spraying (tebuconazole).

\section{CONCLUSIONS}

1) Small slips from 'Pérola' pineapple plants may be converted into planting material of good quality by a nursery phase;

2) Small slips, recuperated by a nursery phase, present an agronomic performance similar to that of conventional slips of the same weight range;

3) Slips present higher growth rates when kept attached to their mother-plants than when placed into a nursery;

4) Independently from the origin of the planting material used, large slips present vegetative and productive performances superior to those of small slips;

5) Slips from vigorous plants of the 'Pérola' pineapple cultivar do not respond significantly to applications of cultural practices, while attached to their mother-plants. 


\section{REFERENCES}

CUNHA, G. A. P. da; REINHARDT, D. H. R. C.; CALDAS, R. C. Efeito da época de plantio, tamanho da muda e idade da planta na indução floral sobre o rendimento do abacaxizeiro 'Pérola' na Bahia. Revista Brasileira de Fruticultura, Cruz das Almas, v.15, n.3, p.43-50, 1993.

CUNHA, G. A. P. da; REINHARDT, D. H. R. C. A propagação do abacaxizeiro. Brasília, DF: Embrapa/SPI, 1994, 70p. (Coleção Plantar, 11. Série Vermelha).

CUNHA, G. A. P. da; MATOS, A. P. de; SANCHES, N. F.; REINHARDT, D. H.; SOUZA, L. F. da S; CABRAL, J. R. S.; ALMEIDA, O. A. de. A cultura do abacaxi: práticas de cultivo. 6 ed. Cruz das Almas, BA: EMBRAPA-CNPMF, 1995.30p. (Circular Técnica, 01).

GAILLARD, J. P. Influence de la date de plantation et du poids des rejets sur la croissance des ananas au Cameroun. Fruits, v.24, n.2, p.75-87, 1969.

GIACOMELLI, E. J.; PY, C.; LOSSOIS, P. Estudo sobre época de produção para o abacaxizeiro Cayenne, no planalto paulista. Anais da Sociedade Brasileira de Fruticultura, Piracicaba, v. 2, p. 499-511, 1979.

IRFA (Institut de Recherches sur les Fruits et Agrumes). La culture de l'ananas d'exportation en Cote d'Ivoire - Manuel du planteur. Abidján: Les Nouvelles Editions Africaines, 1984. 112p.

LIMA, V. P. de, REINHARDT, D. H.; COSTA, J. A. Desbaste de mudas tipo filhote do abacaxi cv. Pérola - 1. Produção e qualidade do fruto. Revista Brasileira de Fruticultura, Jaboticabal, SP, v.23, n.3, p.634638, 2001.

LIMA, V. P. de, REINHARDT, D. H.; COSTA, J. A. Desbaste de mudas tipo filhote do abacaxi cv. Pérola - 2. Análises de crescimento e correlações. Revista Brasileira de Fruticultura, Jaboticabal, SP, v.24, n.1, p.101-107, 2002.
PY, C. Production accelerée de material vegetal de plantation. Fruits, Paris, v.34, n.2, p.107-116, 1979.

PY, C.; LACOEUILHE, J. J.; TEISON, C. L'ananas, sa culture, ses produits. Paris: G.P. Maisonneuve et Larose et A.C.C.T., 1984. 562p.

REBOLLEDO M., A.; URIZA A., D. E.; REBOLLEDO M., L.Tecnologia para la producción de piña en México. Veracruz, INIFAP, Campo Experimental de Papaloapan, 1998. 159p.

REINHARDT, D. H. R. C.; COSTA, J. T. A. CUNHA, G. A. P. da. Influência da época de plantio, tamanho da muda e idade da planta para a indução floral do abacaxi 'Smooth Cayenne' no Recôncavo Baiano. I. Crescimento vegetativo, produção de mudas e florescimento natural. Fruits, Paris, v.41, n.1, p.31-41, 1986.

REINHARDT, D. H. R. C.; COSTA, J. T .A.; CUNHA, G. A. P. da. Influência da época de plantio, tamanho da muda e idade da planta para a indução floral do abacaxi 'Smooth Cayenne' no Recôncavo Baiano. II. Produtividade e características do fruto. Fruits, Paris, v.42, n.1, p.13-23, 1987.

REINHARDT, D. H.; MEDINA, V. M. Crescimento e qualidade do fruto do abacaxi cvs. Pérola e Smooth Cayenne. Pesquisa Agropecuária Brasileira, Brasília, v. 27, n.3, p. 435-447, 1992.

REINHARDT, D. H. Como aumentar a oferta de mudas convencionais de boa qualidade. Cruz das Almas, BA: Embrapa Mandioca e Fruticultura, 1998a. 2p. (Abacaxi em Foco, 10)

REINHARDT, D. H. Manejo e produção de mudas de abacaxi. Informe Agropecuário, Belo Horizonte, v.19, n.195, p.13-19, 1998 b.

REINHARDT, D. H.; SOUZA, L. F. da S.; CABRAL, J. R. S. Abacaxi. Produção: Aspectos técnicos. Brasília, DF: Embrapa Comunicação para Transferência de Tecnologia, 2000. 77p. il; (Frutas do Brasil; 7)

REINHARDT, D. H.; SOUZA, J. da S. Pineapple industry and research in Brazil. Acta Horticulturae, Wageningen, v. 529, p. 57-71, 2000. 